\title{
Elongation factor-1 alpha is a selective regulator of growth factor withdrawal and ER stress-induced apoptosis
}

\author{
S Talapatra ${ }^{1}$, JDO Wagner ${ }^{1}$ and CB Thompson ${ }^{\star, 1}$ \\ 1 Department of Cancer Biology, Abramson Family Cancer Research Institute, \\ University of Pennsylvania, 421 Curie Boulevard, Philadelphia, Pennsylvania, \\ PA 19104-6160, USA \\ * Corresponding author: CB Thompson, Department of Cancer Biology, \\ University of Pennsylvania, 421 Curie Boulevard, Philadelphia, \\ PA 19104-6160, USA. Tel: (215) 746-5515; Fax: (215) 746-5511; \\ E-mail: drt@mail.med.upenn.edu
}

Received 15.3.02; accepted 8.5.02

Edited by DR Green

\begin{abstract}
To identify genes that contribute to apoptotic resistance, IL-3 dependent hematopoietic cells were transfected with a cDNA expression library and subjected to growth factor withdrawal. Transfected cells were enriched for survivors over two successive rounds of IL-3 withdrawal and reconstitution, resulting in the identification of a full-length elongation factor 1 alpha (EF-1 $\alpha$ ) cDNA. Ectopic EF-1 $\alpha$ expression conferred protection from growth factor withdrawal and agents that induce endoplasmic reticulum stress, but not from nuclear damage or death receptor signaling. Overexpression of EF-1 $\alpha$ did not lead to growth factor independent cell proliferation or global alterations in protein levels or rates of synthesis. These findings suggest that overexpression of EF- $1 \alpha$ results in selective resistance to apoptosis induced by growth factor withdrawal and ER stress.
\end{abstract}

Cell Death and Differentiation (2002) 9, 856-861. doi:10.1038/ sj.cdd. 4401078

Keywords: Apoptosis; Bcl-xL; EF-1 $\alpha$; ER; growth factor

Abbreviations: $\mathrm{BH}, \mathrm{Bcl}-2$-homology; $\mathrm{EF}-1 \alpha$, elongation factor 1alpha; ER, endoplasmic reticulum; IL-3, interleukin-3; PCR, polymerase chain reaction; $\mathrm{PI}$, propidium iodide; TNF- $\alpha$, tumor necrosis factor- alpha; UPR, unfolded protein response

\section{Introduction}

Programmed cell death, or apoptosis, is a genetically determined form of cell death that is essential for the development and homeostasis of cellular repertoires in multicellular organisms. Several genes for the execution of apoptosis have been identified, and growing evidence suggests that multiple pathways exist for the integration and initiation of cell death signals. ${ }^{1,2}$ The most direct pathway to activation of programmed cell death involves the engagement of cell surface death receptors, which leads to the activation of receptor proximal initiator caspases. ${ }^{3}$ A second, cell-intrinsic pathway involves the $\mathrm{Bcl}$-2-homology region 3 (BH3)-only containing proteins that directly or indirectly activate proapoptotic proteins Bax and Bak, which initiate apoptosis by promoting mitochondrial dysfunction. ${ }^{4,5}$ Other organellespecific initiators of cell death include the endoplasmic reticulum (ER), which can sense perturbations in $\mathrm{Ca}^{2+}$ homeostasis or protein folding and trigger apoptosis by the unfolded protein response (UPR) and the ER-specific protease, caspase-12.,7 Additionally, the nucleus can detect DNA damage and initiate apoptosis through activation of p53 and stress kinases. ${ }^{8}$ Thus, it appears that organelle- and stimulus-specific apoptosis pathways exist.

Bcl-2-related proteins are an evolutionarily conserved gene family that act as central regulators of apoptosis. Antiapoptotic members of the Bcl-2 family, such as $\mathrm{Bcl}-\mathrm{x}_{\mathrm{L}}$, are able to prevent apoptosis by facilitating mitochondrial homeostasis. ${ }^{9}$ Expression of these proteins appears to increase resistance to multiple apoptotic stimuli. ${ }^{10-12}$ In contrast, relatively little is known about stress-specific inhibitors of apoptosis, and the regulation of specific survival pathways remains incompletely understood.

In an effort to identify novel regulatory genes that can antagonize cell death, we initiated a screen of a HeLa cDNA expression library for genes that inhibit apoptosis in IL-3 dependent FL5.12 cells. Transfected populations were enriched for cells surviving two successive rounds of IL-3 withdrawal and reconstitution. Clonal populations were isolated and the cDNA rescued by polymerase chain reaction $(\mathrm{PCR})$. One of the clones isolated contained a full-length elongation factor 1-alpha (EF-1 $\alpha)$ cDNA that protected from death following IL-3 withdrawal upon retransfection. EF- $1 \alpha$ is an evolutionarily conserved GTPase that catalyzes the efficient delivery of charged tRNA to the ribosome during protein elongation and is critically involved in translation fidelity. ${ }^{13,14}$ Here we show that enforced EF-1 $\alpha$ expression provides dose-dependent protection from growth factor withdrawal without transforming cells. EF- $1 \alpha$ expression does not protect from nuclear or death receptor initiated apoptosis, but does prevent death from ER stress. These findings suggest a role for EF- $1 \alpha$ as a regulator of ER stress and growth factor withdrawalinduced apoptosis.

\section{Results}

To better understand signaling events that affect programmed cell death, we designed a screening strategy to identify complete or partial human genes that conferred survival under conditions where apoptosis is normally induced. When deprived of IL-3, FL5.12 cells rapidly initiate apoptosis and cannot be rescued by cytokine readdition after $36 \mathrm{~h}$. FL5.12 cells are well-studied, non-transformed murine pro-B cells that require IL-3 for growth, survival, and proliferation. ${ }^{16} \mathrm{~A}$ unidirectional cDNA library from HeLa adenocarcinoma cells 
in the mammalian expression vector pcDNA3.1 was transfected into 10 independent populations of $1 \times 10^{7}$ FL5.12 cells. Cells were allowed to recover from electroporation for 1 day in complete medium and then withdrawn from IL-3 for 2 days. Less than $1 \%$ of vector control transfected or untransfected cells remained viable after $48 \mathrm{~h}$ in the absence of growth factor, as measured by their ability to exclude propidium iodide (Figure 1). To ensure stable integration of the library plasmids, surviving populations were selected for genomic integration of the cDNA insert in the presence of G418 following $24 \mathrm{~h}$ of IL-3 readdition (Figure 1).

At the completion of one round of this selection protocol, all 10 cDNA transfected populations contained viable cells, while no cells could be recovered from the control populations. To reduce the number of false positives, G418-resistant populations that survived the initial round of IL-3 deprivation were subjected to a second round of IL-3 withdrawal. Further rounds of selection did not appear to enrich for survivors as judged by recovery from selection at limiting dilutions (data not shown). Therefore, populations that survived the second round were cloned and CDNA insertions from clonal populations were rescued by PCR. The amplified PCR fragments were cloned into the pSFFV expression vector, retransfected into FL5.12 cells, and screened for the capacity to confer IL-3-independent survival. Of the 11 clones analyzed, one clone was able to promote survival following IL-3 withdrawal in multiple independent transfections. The sequence of the $1284 \mathrm{bp}$ cloned cDNA was determined and found to contain the complete open reading frame of human elongation factor-1 alpha $(E F-1 \alpha)$ gene. ${ }^{14}$

To determine the kinetics of EF- $1 \alpha$ protection from cell death, populations of FL5.12 cells constitutively overexpressing murine $\mathrm{EF}-1 \alpha$ or human $\mathrm{Bcl}-\mathrm{x}_{\mathrm{L}}$ protein were established and survival following IL-3 withdrawal was

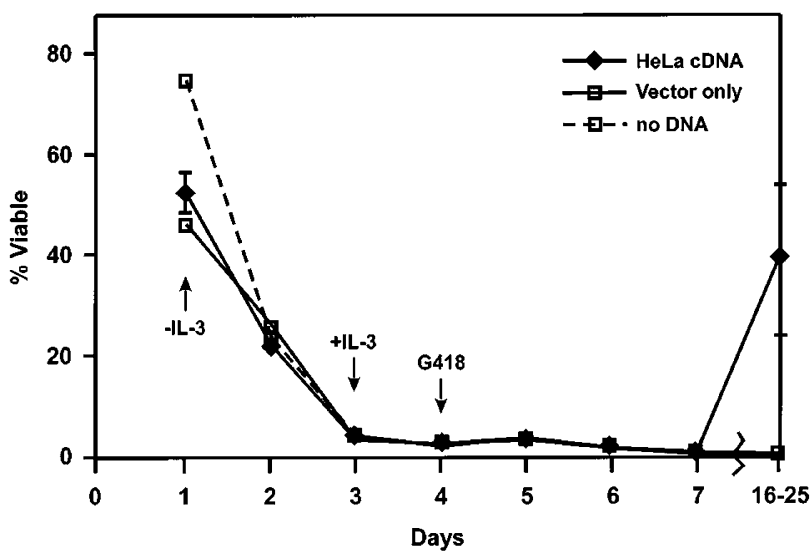

Figure 1 Viability of cell populations screened for genes that antagonize apoptosis. FL5.12 cells were transfected with a HeLa cDNA library, empty vector, or no DNA. The viability of surviving populations, as measured by the ability to exclude propidium iodide (PI), was assessed over time by flow cytometry. IL-3 was removed and reconstituted at the indicated times. Geneticin (G418) was added at day 4. Viable cells were recovered 16-25 days post-transfection. The mean \pm S.D. of 10 independent populations is plotted for the cDNA-containing populations compared (Figure 2A). As previously reported, overexpression of $\mathrm{Bcl}-\mathrm{x}_{\mathrm{L}}$ promoted survival in the absence of growth factor (Figure 2B). ${ }^{16}$ EF-1 $\alpha$ overexpression retarded death kinetics and conferred a similar magnitude of protection to that of $\mathrm{Bcl}-\mathrm{x}_{\mathrm{L}}$ at $24 \mathrm{~h}$ without IL-3. Expression of EF-1 $\alpha$ did

A.

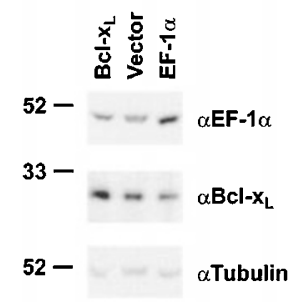

B.

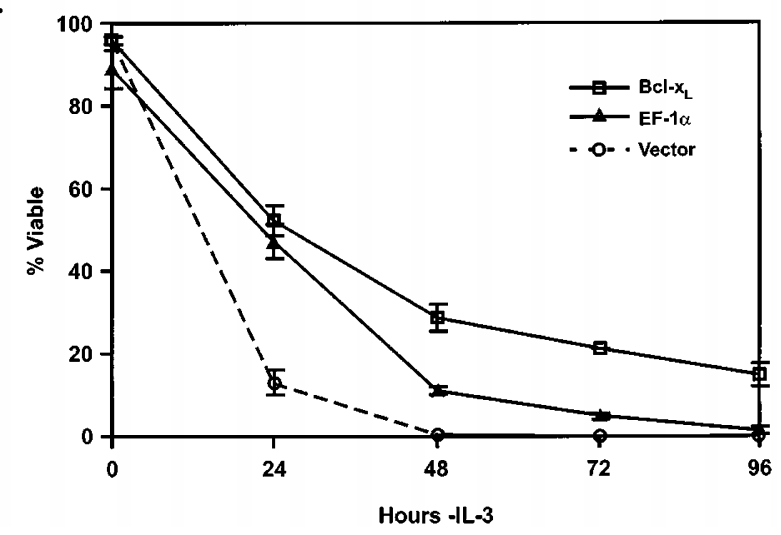

C.

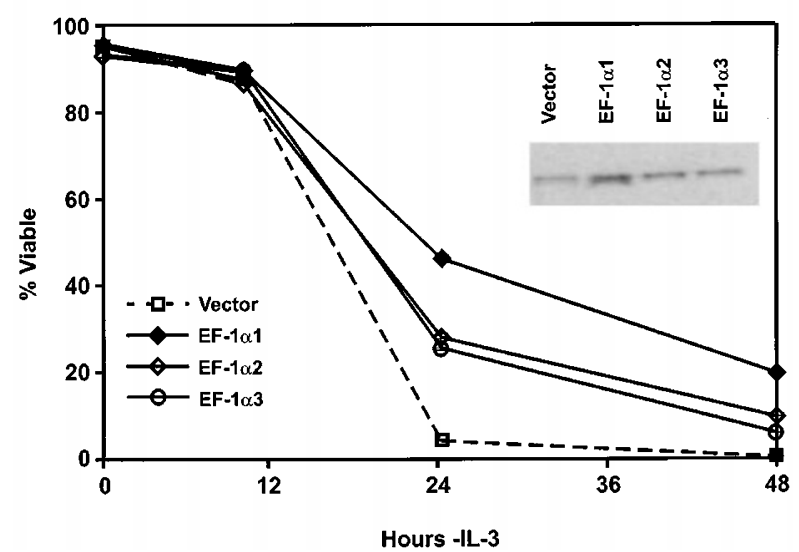

Figure 2 EF-1 $\alpha$ protects FL5.12 cells from IL-3 withdrawal induced cell death in a dose-dependent manner. (A) Lysates from EF- $1 \alpha, \mathrm{Bcl}-\mathrm{x}_{\mathrm{L}}$, or vector expressing cells were standardized for protein content and immunoblotted for EF-1 $\alpha, B c l-x_{\mathrm{L}}$, or tubulin (loading control) as indicated. (B) Cells were transfected with $\mathrm{EF}-1 \alpha, \mathrm{Bcl}-\mathrm{x}_{\mathrm{L}}$, or empty pSFFV vector in FL5.12 cells. G418 resistant populations were deprived of IL-3 and their viability plotted over time as an average of three independent trials. (C) Clones expressing high and moderate levels of EF- $1 \alpha$ were withdrawn from IL-3 and their viability assessed as above. The three EF- $1 \alpha$ clones and a vector control cell line were chosen on the basis of their protein expression levels as determined by immunoblotting (inset). The data presented represent the mean \pm S.D. of three independent experiments 
not alter endogeneous $\mathrm{Bcl}-\mathrm{x}_{\mathrm{L}}$ protein levels (Figure $2 \mathrm{~A}$ ), suggesting that survival was by an independent mechanism. Both $\mathrm{EF}-1 \alpha$ - and $\mathrm{Bcl}-\mathrm{x}_{\mathrm{L}}$ - expressing viable cells could be detected at least 3 days after growth factor withdrawal and recovered by IL-3 readdition, while vector control cells were no longer viable under these conditions (data not shown).

We next investigated the correlation between EF-1 $\alpha$ protein expression levels and the magnitude of survival. Independent clones expressing high (EF-1 $\alpha 1)$ and moderate $(E F-1 \alpha 2$ and $E F-1 \alpha 3)$ levels of $E F-1 \alpha$ protein were chosen for further analysis (for relative expression levels see inset box, Figure 2C). In the absence of IL-3, EF- $1 \alpha$ expression levels correlated with the magnitude of survival with highest expression conferring the best survival (Figure $2 \mathrm{C})$. These data show that the constitutive overexpression of EF- $1 \alpha$ protects FL5.12 cells from IL-3 withdrawal-induced death and that this protection is dose-dependent.

The constitutive expression of EF- $1 \alpha$ has been reported to lead to transformation. ${ }^{17}$ We therefore investigated whether the protection observed in FL5.12 cells was a consequence of IL-3-independent proliferation. Cells were incubated with the nucleotide analog BrdU, and the BrdU incorporated into newly synthesized DNA was used to determine the percentage of cycling cells in the population. In the presence of growth factor, all populations incorporated $\mathrm{BrdU}$ (Figure 3). However, $48 \mathrm{~h}$ after IL-3 withdrawal, both $\mathrm{EF}-1 \alpha$ and $\mathrm{Bcl}-\mathrm{x}_{\mathrm{L}}$ overexpressing cells had exited the cell cycle as both populations no longer incorporated BrdU but contained high numbers of viable cells. Further analysis showed that both populations withdrew from the cell cycle and arrested in G1 (data not shown). Thus, overexpression of EF-1 $\alpha$ in FL5.12 cells does not obviate the need for IL-3 signaling for cell proliferation, ${ }^{16}$ and the enhanced survival in the absence of growth factor observed in these populations does not result from IL-3-independent proliferation.

Mammalian EF-1 $\alpha$ shares homology with the bacterial translation protein EF-Tu, and both proteins are essential for protein synthesis. Manipulation of EF-1 $\alpha$ protein levels has been reported to alter total cellular protein levels through mechanisms involving both protein synthesis and degradation. ${ }^{18}$ Therefore, steady state protein levels and rates of protein synthesis were assessed. First, total cellular protein levels were compared. The enforced expression of EF-1 $\alpha$ did not appear to affect the total protein content in the presence or absence of IL-3 (Figure 4A). To further evaluate cellular protein content and distribution, 2-dimensional (2D) gel electrophoresis was performed. No reproducible alterations in the distribution of proteins in EF- $1 \alpha$ overexpressing cells relative to vector control counterparts were found (data not shown). Consistent with cell mass measurements, the size of EF-1 $\alpha$ overexpressing cells revealed no significant differences with control cells in the presence or absence of IL-3 (data not shown). We next investigated the kinetics of protein synthesis. EF-1 $\alpha$ expressing cells incorporated similar amounts of ${ }^{35} \mathrm{~S}$-methionine relative to control populations in both the presence or absence of IL-3 (Figure 4B). Thus, enforced expression of EF- $1 \alpha$ does not affect total cellular
+ IL-3
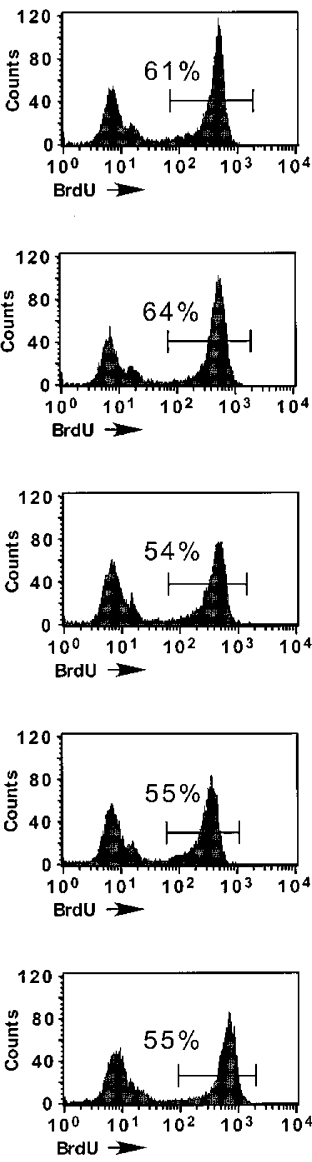

$E F-1 \propto 3$

-IL-3

Vector

Bcl- $x_{L}$

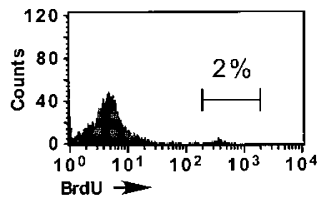

EF-1 $1 \alpha 1$

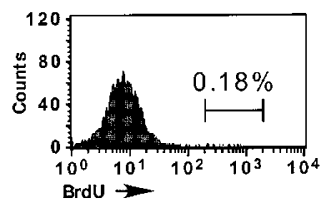

$\mathrm{EF}-1 \alpha 2$
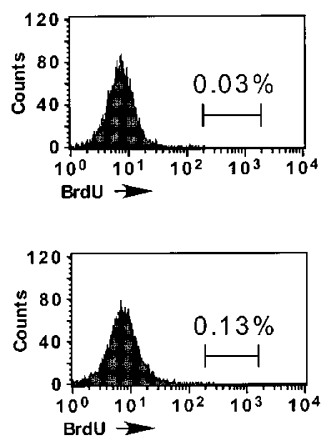

Figure 3 EF- $1 \alpha$ expression promotes cell survival independent of proliferation. $\mathrm{EF}-1 \alpha$ and $\mathrm{Bcl}-\mathrm{x}_{\mathrm{L}}$ overexpressing clones were grown with or without IL-3 for $48 \mathrm{~h}$, incubated with BrdU, and analyzed by flow cytometry. The percentage of BrdU positive events was calculated after gating to remove sub-diploid events

protein content, cell size, or the rate of protein synthesis in FL5.12 cells.

Apoptosis can be triggered through multiple pathways, including death receptor engagement, nuclear DNA damage, and ER stress. In order to determine the scope of EF- $1 \alpha$ mediated protection, we assayed EF-1 $\alpha$ antiapoptotic activity in response to UV irradiation, treatment with TNF- $\alpha$ and cycloheximide $(\mathrm{CHX})$, etoposide, brefeldin A (BFA), and thapsigargin. EF-1 $\alpha$ overexpression had no effect on apoptosis in response to the nuclear stress agents, UV irradiation and etoposide, while $\mathrm{Bcl}-\mathrm{x}_{\mathrm{L}}$ expression was protective, suggesting that the ability of EF-1 $\alpha$ to promote survival is distinct from that of $\mathrm{Bcl}-\mathrm{x}_{\mathrm{L}}$ (Figure 5 and data not shown). EF-1 $\alpha$ expression did not interfere with activation of the death receptor pathway as TNF- $\alpha / \mathrm{CHX}$ treatment led to rapid loss of viability. In contrast, each of the two EF- $1 \alpha$ clones examined conferred durable, longterm survival advantage from the ER stress agents, BFA and thapsigargin (Figure 5). BFA reversibly blocks protein transport between the ER and Golgi, ${ }^{19}$ while thapsigargin inhibits the ER $\mathrm{Ca}^{2+}$-ATPase family of calcium pumps. ${ }^{20} \mathrm{~A}$ 
A.
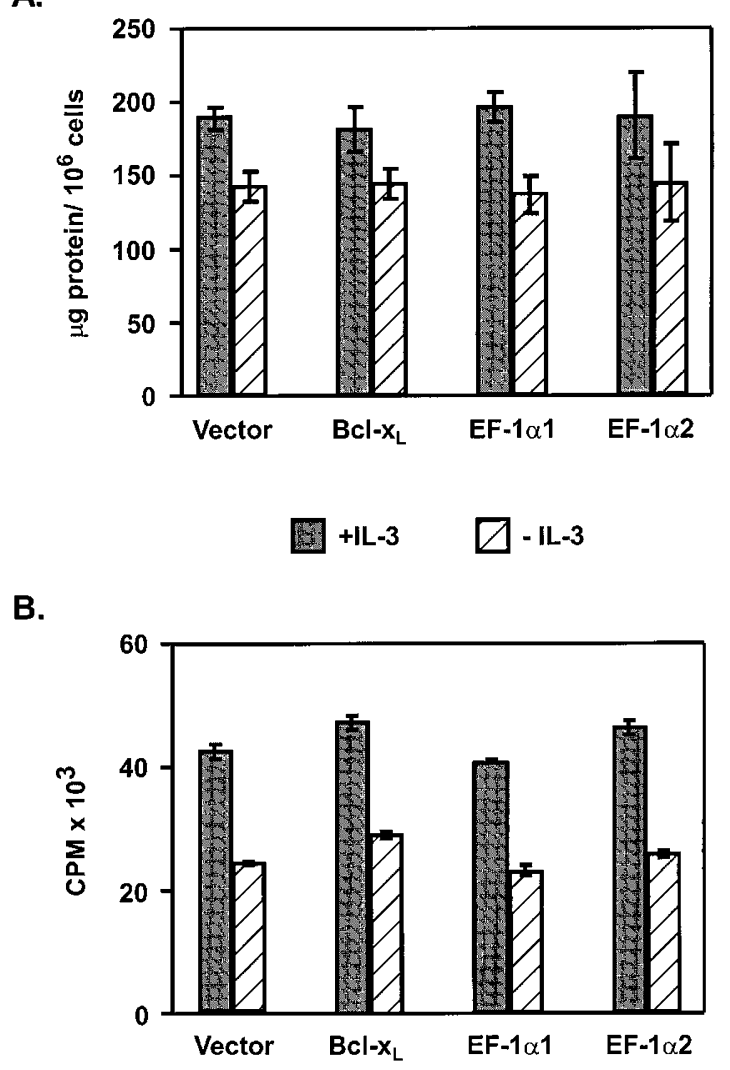

Figure 4 EF-1 $\alpha$ overexpression does not affect total protein levels or rate of synthesis. (A) Total protein content using BCA reagent was assessed from equal numbers of cells grown for $8 \mathrm{~h}$ in the presence or absence of IL-3. (B) Equal numbers of cells were grown in the presence or absence of IL-3 for $6 \mathrm{~h}$ and then pulsed with ${ }^{35} \mathrm{~S}$-methonine for $30 \mathrm{~min}$. Total incorporation of radioactive label was quantified by TCA precipitation followed by scintillation counting. The mean \pm S.D. of three independent samples is presented

reduction in the rate of cell death following treatment with the protein glycosylation inhibitor, tunicamycin, ${ }^{21}$ a third ER stress agent was also observed (data not shown). In all the ER stress treatments, the magnitude of protection directly correlated with the level of EF- $1 \alpha$ expression. Thus, EF-1 $\alpha$ retards apoptosis induced by $E R$ stress in a dosedependent manner.

\section{Discussion}

We have identified EF- $1 \alpha$ from a screen for genes that protect IL-3 dependent cells from growth factor withdrawal-induced death. EF- $1 \alpha$ is a GTPase that has multiple and divergent roles in cell physiology affecting the cytoskeleton, peptide synthesis and protein degradation. ${ }^{18,22,23}$ We have found that the enforced expression of EF-1 $\alpha$ can promote long-term viability from growth factor withdrawal-induced death in proportion to its level of expression. EF- $1 \alpha$ protection does not extend to nuclear DNA damaging agents nor activation of TNF death receptors. However, EF-1 $\alpha$ expression provides significant protection from all ER stress inducing agents assayed.
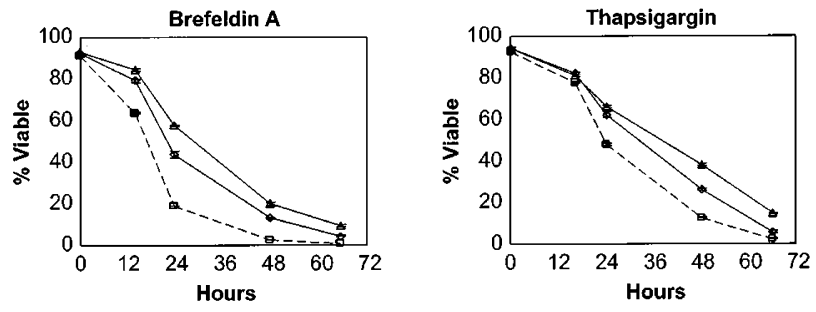

$$
\begin{aligned}
& \text { - Vector } \\
& \triangle-E F-1 \alpha 1 \\
& \rightarrow \text { EF-1 } \alpha 2
\end{aligned}
$$
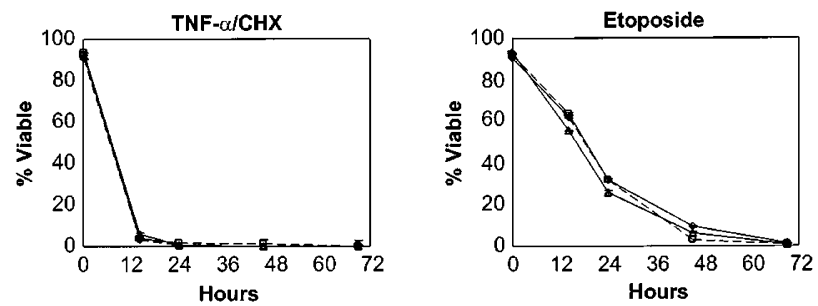

Figure 5 EF- $1 \alpha$ expression protects FL5.12 cells from ER, but not nuclear, stress. Equal numbers of cells were grown in the presence of IL-3 and treated with either $10 \mathrm{ng} / \mathrm{ml} \mathrm{TNF}-\alpha$ and $10 \mu \mathrm{g} / \mathrm{ml}$ with cycloheximide (TNF- $\alpha / \mathrm{CHX}$ ), $100 \mu \mathrm{M}$ etoposide, $1 \mu \mathrm{g} / \mathrm{ml}$ brefeldin $\mathrm{A}$, or $1 \mu \mathrm{M}$ thapsigargin, as indicated. Viability was assessed by $\mathrm{PI}$ exclusion over time using a flow cytometer. The mean \pm S.D. of three readings is presented

Overexpressing EF-1 $\alpha$ in FL5.12 cells renders them refractory to IL-3 deprivation-induced cell death, although these cells remain dependent on IL-3 signaling for growth and proliferation. Previous findings suggest that the constitutive expression of EF-1 $\alpha$ can sensitize cultured cells to transformation by chemical agents or irradiation, but is not itself transforming. ${ }^{17}$ The results reported here provide a molecular explanation for these earlier observations. EF-1 $\alpha$ may create an environment suitable for mutagens to induce transformation by increasing cellular resistance to apoptosis as has been proposed for $\mathrm{Bcl}-2$ and $\mathrm{BCl}-\mathrm{X}_{\mathrm{L}}{ }^{24}$

As $E F-1 \alpha$ is an essential translation elongation factor, the effect of EF-1 $\alpha$ overexpression on peptide synthesis was investigated. It is unclear whether enforced EF-1 $\alpha$ expression can affect rates of protein translation. ${ }^{18,25,26} \mathrm{We}$ did not detect global effects on protein levels or rates of production. The lack of changes in global protein production does not rule out, however, that enduring EF-1 $\alpha$ expression may alter the expression of individual proteins that protect the cell from apoptosis. In such an event, enforced EF- $1 \alpha$ expression would allow for the expression of cellular stress response proteins under apoptotic conditions where rates of protein production significantly and progressively decline. ${ }^{27-29}$ In this model, if a specific regulator of apoptosis were affected, it is unlikely to be one that protects from multiple apoptotic stimuli such as prosurvival proteins of the Bcl-2 family, as the overexpression of EF-1 $\alpha$ provides no protection from apoptosis initiated by DNA damage, where $\mathrm{Bcl}-\mathrm{x}_{\mathrm{L}}$ is protective.

The role of $\mathrm{EF}-1 \alpha$ in survival may not require its function in peptide elongation. EF- $1 \alpha$ has an established role in maintaining and enhancing translational fidelity. Both the 
codon specific binding of amino-acyl-tRNA with its complimentary anticodon and the rejection of mismatches (proofreading) require the activity of EF- $1 \alpha^{30-32}$ One important effect of reduced translation fidelity is an increase in the frequency of proteins that are no longer able to adopt their native conformation due to amino acid misincorporation. Such changes in protein content and folding could be recognized in the $E R$, an organelle ideally suited to detect changes in protein fidelity, where nearly a third of proteins are thought to be processed. ${ }^{33}$

The ER is a protein dense organelle that houses chaperones for the proper modification and folding of nascent polypeptides. Accumulating unfolded proteins form aggregates which can initiate an ER specific unfolded protein response (UPR) and ultimately apoptosis. ${ }^{34-36}$ If increasing EF- $1 \alpha$ levels increases translation accuracy, the overexpression of $\mathrm{EF}-1 \alpha$ may lead to a reduction of unfolded proteins in the ER.

What might IL-3 deprivation and ER stress have in common? The attenuation of glucose uptake has been observed within hours of IL-3 withdrawal, ${ }^{37}$ in part resulting from the removal of nutrient transporters from the cell surface. ${ }^{38}$ Glucose deprivation, in turn, has been demonstrated to induce ER stress by perturbing protein glycosylation in the ER. ${ }^{39}$ Overexpression of EF- $1 \alpha$ may reduce the rate at which intracellular glucose is depleted through ER glycosylation of proteins that are ultimately degraded because of translational errors. This model provides an explanation for the selective anti-apoptotic advantage for the elevated levels of EF- $1 \alpha$ observed during neoplasic transformation and in tumors. ${ }^{40}$

\section{Materials and Methods}

\section{Cell culture}

FL5.12 cells were cultured in RPMI-1640 (Gibco BRL) supplemented with $10 \%$ fetal bovine serum (FBS) (Clontech), $300 \mathrm{pg} / \mathrm{ml}$ recombinant IL-3 (rlL3) (Pharmingen), $20 \mathrm{mM}$ HEPES, $50 \mu \mathrm{M}$ 2-mercaptoethanol, $100 \mathrm{U} / \mathrm{ml}$ penicillin, and $100 \mu \mathrm{g} / \mathrm{ml}$ streptomycin. Methionine-free media was made using glutamine-, methionine-, and cystine- free RPMI 1640 (Mediatech), supplemented with $300 \mathrm{mg} / \mathrm{l}$ glutamine, $65 \mathrm{mg} / \mathrm{l}$ cystine, dialysed FBS (Gibco BRL), HEPES, 2-mercaptoethanol, penicillin, and streptomycin. Where indicated, cells were treated with either $10 \mathrm{ng} / \mathrm{ml}$ Tumor Necrosis Factor- $\alpha$ and $10 \mu \mathrm{g} / \mathrm{ml}$ cycloheximide (TNF- $\alpha / \mathrm{CHX),} 200 \mathrm{~J} / \mathrm{m}^{2}$ ultraviolet radiation (UV), $100 \mu \mathrm{M}$ etoposide (Sigma), $1 \mu \mathrm{g} / \mathrm{ml}$ brefeldin A (BFA, Sigma), $1 \mu \mathrm{M}$ thapsigargin (Sigma), or $10 \mu \mathrm{g} / \mathrm{ml}$ tunicamycin. Cell number and size measurements were made using a Coulter Z2 instrument (Beckman Coulter).

\section{Screening of expression library}

Ten independent populations of 10 million cells were transfected with $10 \mu \mathrm{g}$ each of HeLa cDNA library (Invitrogen). Cells were allowed to recover from electroporation for $24 \mathrm{~h}$ before withdrawal from IL-3 by washing three times with RPMI 1640. After 2 days, recombinant IL-3 was reconstituted $(300 \mathrm{pg} / \mathrm{ml})$ and cells allowed to recover for 1 day before selection in $1 \mathrm{mg} / \mathrm{ml}$ Geneticin (Gibco BRL). Cells were cloned under limiting dilution conditions and cDNA insert amplified using
Expand High Fidelity PCR System (Roche Molecular Biochemicals) with primers 5'-CATTGACGCAAATGGGCGGTAGGCGTG and 5'GGCAACTAGAAGGCACAGTCGTGGCTGAT flanking the multiple cloning site of pcDNA3.1. Murine EF- $1 \alpha$ constructs were generously provided by E Wang, McGill University, Canada. EF01 $\alpha$ was PCR amplified with 5'-CGGAATTCGCAAAAATGGGAAAGGAAAAGACTCAC and 5'-CGGAATTCTCATTTAGCCTTCTGAGC primers and cloned into the EcoRI site of pSFFV vector ${ }^{15}$ for further study. Following PCR, the EF- $1 \alpha$ sequence was verified by DNA sequencing.

\section{Protein studies}

Cells were lyzed in $0.05 \%$ NP-40 buffer with protease inhibitors (Complete, Roche), standardized for protein content, and separated by SDS-PAGE (Invitrogen). Following transfer to nitrocellulose, blots were probed with either mouse anti-EF1 $\alpha$ (Upstate Biotechnology), rabbit anti-Bcl- $\mathrm{x}_{\mathrm{L}}$, or mouse anti-tubulin (Santa Cruz). Horseradish peroxidase-conjugated anti-rabbit (New England Biolabs) or antimouse (Promega) secondary antibodies were added to immunoblots and visualized by enhanced chemiluminescence (Amersham Pharmacia Biotech). For total protein measurements, $5 \times 10^{5}$ cells were washed once with PBS, lysed, and protein content assessed using BCA protein assay reagent (Pierce). To determine the rate of protein synthesis, $5 \times 10^{5}$ cells were washed twice and incubated for $15 \mathrm{~min}$ in methionine-free RPMI 1640 supplemented with or without rlL-3 to deplete intracellular methionine stores. Cells were then pulsed with $5 \mu \mathrm{Ci}{ }^{35} \mathrm{~S}$-methionine for $30 \mathrm{~min}$, washed once with cold PBS, and lysed in RIPA with protease inhibitors (Complete, Roche). Labeled proteins were precipitated with $10 \%$ trichloroacetic acid and radioactivity determined by scintillation counting (Wallac).

\section{Cell viability assays}

To determine cell viability, cells were washed three times in RPMI1640 and resuspended to a density of $2 \times 10^{5}$ cells $/ \mathrm{ml}$ in complete media lacking IL-3. Samples were removed at the indicated time points and propidium iodide (PI, Molecular Probes) added to a final concentration of $4 \mu \mathrm{g} / \mathrm{ml}$. Analysis was completed in a FacsCalibur flow cytometer (Becton Dickinson). For ER stress agents, an appropriate dose was selected from a range of concentrations tested. BFA was titrated between 1 and $100 \mu \mathrm{g} / \mathrm{ml}$, thapsigargin from 0.2 to $20 \mu \mathrm{M}$, and 0.1 and $100 \mu \mathrm{g} / \mathrm{ml}$ for tunicamycin.

\section{Acknowledgments}

We thank members of the Thompson Lab, including Aimee Edinger and David Plas, for their scientific input.

\section{References}

1. Ferri KF and Kroemer G (2001) Organelle-specific initiation of cell death pathways. Nat. Cell. Biol. 3: E255-E263

2. Talapatra $S$ and Thompson $C B$ (2001) Growth factor signaling in cell survival: implications for cancer treatment. J. Pharmacol. Exp. Ther. 298: 873-878

3. Rathmell JC and Thompson CB (1999) The central effectors of cell death in the immune system. Annu. Rev. Immunol. 17: 781-828

4. Desagher S and Martinou JC (2000) Mitochondria as the central control point of apoptosis. Trends Cell Biol. 10: 369-377

5. Huang DC and Strasser A (2000) BH3-Only proteins-essential initiators of apoptotic cell death. Cell 103: 839-842 
6. Nakagawa T, Zhu H, Morishima N, Li E, Xu J, Yankner BA and Yuan J (2000) Caspase-12 mediates endoplasmic-reticulum-specific apoptosis and cytotoxicity by amyloid-beta. Nature 403: $98-103$

7. Yoneda T, Imaizumi K, Oono K, Yui D, Gomi F, Katayama T and Tohyama M (2001) Activation of caspase-12, an endoplastic reticulum (ER) resident caspase, through tumor necrosis factor receptor-associated factor 2- dependent mechanism in response to the ER stress. J. Biol. Chem. 276: 13935 - 13940

8. Zhou BB and Elledge SJ (2000) The DNA damage response: putting checkpoints in perspective. Nature 408: 433-439

9. Vander Heiden MG, Chandel NS, Williamson EK, Schumacker PT and Thompson CB (1997) Bcl-xL regulates the membrane potential and volume homeostasis of mitochondria. Cell 91: 627-637

10. Kluck RM, Bossy-Wetzel E, Green DR and Newmeyer DD (1997) The release of cytochrome $\mathrm{c}$ from mitochondria: a primary site for $\mathrm{Bcl}-2$ regulation of apoptosis. Science 275: $1132-1136$

11. Yang J, LiuX, Bhalla K, Kim CN, Ibrado AM, Cai J, Peng TI, Jones DP and Wang X (1997) Prevention of apoptosis by Bcl-2: release of cytochrome c from mitochondria blocked. Science 275: 1129-1132

12. Bossy-WetzelE, NewmeyerDD and Green DR (1998) Mitochondrial cytochrome crelease in apoptosis occurs upstream of DEVD-specific caspase activation and independently of mitochondrial transmembrane depolarization. EMBO J. 17: $37-49$

13. Negrutskii BS and El'skaya AV (1998) Eukaryotic translation elongation factor 1 alpha: structure, expression, functions, and possible role in aminoacyl-tRNA channeling. Prog. Nucleic Acid Res. Mol. Biol. 60: 47-78

14. Uetsuki T, Naito A, Nagata S and Kaziro Y (1989) Isolation and characterization of the human chromosomal gene for polypeptide chain elongation factor-1 alpha. J. Biol. Chem. 264: 5791-5798

15. Fuhlbrigge RC, Fine SM, Unanue ER and Chaplin DD (1988) Expression of membrane interleukin 1 by fibroblasts transfected with murine pro-interleukin 1 alpha cDNA. Proc. Natl. Acad. Sci. USA 85: 5649-5653

16. Boise LH, Gonzalez-Garcia M, Postema CE, Ding L, Lindsten T, Turka LA, Mao X, Nunez G and Thompson CB (1993) Bcl-x, a Bcl-2-related gene that functions as a dominant regulator of apoptotic cell death. Cell 74: 597-608

17. Tatsuka M, Mitsui H, Wada M, Nagata A, Nojima H and Okayama H (1992) Elongation factor-1 alpha gene determines susceptibility to transformation Nature 359: 333-336

18. Gonen H, Dickman D, Schwartz AL and Ciechanover A (1996) Protein synthesis elongation factorEF-1 alpha is an isopeptidase essential for ubiquitin-dependent degradation of certain proteolytic substrates. Adv. Exp. Med. Biol. 389:209-219

19. Lippincott-Schwartz J, Glickman J, Donaldson JG, Robbins J, Kreis TE, Seamon KB, Sheetz MP and Klausner RD (1991) Forskolin inhibits and reverses the effects of brefeldin A on Golgi morphology by a cAMP-independent mechanism. J. Cell. Biol. 112: 567-577

20. Lytton J, Westlin M and Hanley MR (1991) Thapsigargin inhibits the sarcoplasmic or endoplasmic reticulum $\mathrm{Ca}$ - ATPase family of calcium pumps. J. Biol. Chem. 266: 17067-17071

21. Duksin D and Mahoney WC (1982) Relationship of the structure and biological activity of the natural homologues of tunicamycin. J. Biol. Chem. 257: 31053109

22. Yang F, Demma M, Warren V, Dharmawardhane S and Condeelis J (1990) Identification of an actin-binding protein from Dictyostelium as elongation factor 1a. Nature 347: $494-496$
23. Shiina N, Gotoh Y, Kubomura N, Iwamatsu A and Nishida E (1994) Microtubule severing by elongation factor 1 alpha. Science 266: $282-285$

24. Minn AJ, Rudin CM, Boise LH and Thompson CB (1995) Expression of bcl-xLcan confer a multidrug resistance phenotype. Blood 86: 1903-1910

25. Duttaroy A, Bourbeau D, Wang XL and Wang E (1998) Apoptosis rate can be accelerated or decelerated by overexpression or reduction of the level of elongation factor-1 alpha. Exp. Cell. Res. 238: 168-176

26. Munshi R, Kandl KA, Carr-Schmid A, Whitacre JL, Adams AE and Kinzy TG (2001) Overexpression of translation elongation factor $1 \mathrm{~A}$ affects the organization and function of the actin cytoskeleton in yeast. Genetics 157 $1425-1436$

27. Deckwerth TL and Johnson Jr EM (1993) Temporal analysis of events associated with programmed cell death (apoptosis) of sympathetic neurons deprived of nerve growth factor. J. Cell. Biol. 123: 1207-1222

28. Marissen WE and Lloyd RE (1998) Eukaryotic translation initiation factor $4 G$ is targeted for proteolytic cleavage by caspase 3 during inhibition of translation in apoptotic cells. Mol. Cell. Biol. 18: 7565-7574

29. Scott CE and Adebodun F (1999) 13C-NMR investigation of protein synthesis during apoptosis in human leukemic cell lines. J. Cell Physiol. 181: 147-152

30. Carr-Schmid A, Durko N, Cavallius J, MerrickWC and Kinzy TG(1999) Mutations in a GTP-binding motif of eukaryotic elongation factor $1 \mathrm{~A}$ reduce both translational fidelity and the requirement for nucleotide exchange. J. Biol. Chem. 274: 30297-30302

31. Thompson RC and Stone PJ (1977) Proofreading of the codon-anticodon interaction on ribosomes. Proc. Natl. Acad. Sci. USA 74: 198-202

32. Dinman JD and Kinzy TG (1997) Translational misreading: mutations in translation elongation factor 1alpha differentially affect programmed ribosoma frameshifting and drug sensitivity. RNA 3: 870-881

33. Chevet E, Cameron PH, Pelletier MF, Thomas DY and Bergeron JJ (2001) The endoplasmic reticulum: integration of protein folding, quality control, signaling and degradation. Curr. Opin. Struct. Biol. 11: 120-124

34. Kozutsumi Y, Segal M, Normington K, Gething MJ and Sambrook J (1988) The presence of malfolded proteins in the endoplasmic reticulum signals the induction of glucose-regulated proteins. Nature 332: 462-464

35. Ma $Y$ and Hendershot LM (2001) The unfolding tale of the unfolded protein response. Cell 107: 827-830

36. Kaufman RJ (1999) Stress signaling from the lumen of the endoplasmic reticulum: coordination of gene transcriptional and translational controls. Genes Dev. 13: $1211-1233$

37. Plas DR, Talapatra S, Edinger AL, Rathmell JC and Thompson CB (2001) Akt and $\mathrm{Bcl}-\mathrm{xL}$ promote growth factor-independent survival through distinct effects on mitochondrial physiology. J. Biol. Chem. 276: 12041-12048

38. Rathmell JC, Vander Heiden MG, Harris MH, Frauwirth KA and Thompson CB (2000) In the absence of extrinsic signals, nutrient utilization by lymphocytes is insufficient to maintain either cell size or viability. Mol. Cell. 6: 683-692

39. Scheuner D, Song B, McEwen E, Liu C, Laybutt R, Gillespie P, Saunders T, Bonner-Weir S and Kaufman RJ (2001) Translational control is required for the unfolded protein response and in vivo glucose homeostasis. Mol. Cell. 7: 11651176

40. Grant AG, Flomen RM, Tizard ML and GrantDA(1992) Differential screening of a human pancreatic adenocarcinoma lambda gt11 expression library has identified increased transcription of elongation factor EF-1 alpha in tumour cells. Int. J. Cancer 50: 740-745. 